\title{
DETERMINAN INDEKS KEBAHAGIAAN DI INDONESIA
}

\author{
Immawan Azhar Ben Atasoge \\ Email: imawanazhar07@gmail.com \\ Program Studi Ekonomi Syariah Sekolah Tinggi Ekonomi Syariah Tunas Palapa
}

\begin{abstract}
ABSTRAK
Tolok ukur untuk melihat kemakmuran sebuah Negara dapat dilihat dari GDP yang ada di negara tersebut. Ukuran kesejahteraan tidak hanya diukur berdasarkan substansi akan tetapi diukur berdasarkan keadaan subjektif atau kebahagiaan. Tujuan dari penelitian ini ialah mengetahui faktor yang mempengaruhi kebahagiaan di Indonesia periode 2014 dan 2017. Analisis yang digunakan yaitu model regresi data panel. Penelitian ini menunjukkan bahwa variabel pendidikan, kesehatan, indeks gini serta zis berpengaruh secara terhadap kebahagiaan di Indonesia. Sedangkan variabel PDRB per kapita, kemiskinan, dan Indeks Demokrasi.
\end{abstract}

Kata Kunci: Indeks Kebahagiaan, IPM, Kemiskinan, Indeks Gini, Zakat, Indeks Demokrasi

\begin{abstract}
The benchmark for seeing the prosperity of a country can be seen from the GDP in that country. The measure of well-being is not only measured based on substance but is measured based on subjective states or happiness. The purpose of this study is to determine the factors that influence happiness in Indonesia for the period 2014 and 2017. The analysis used is a panel data regression model. This study shows that the variables of education, health, Gini index and zis have a significant effect on happiness in Indonesia. While the variables are per capita GRDP, poverty, and the Democracy Index.
\end{abstract}

Keywords: Happiness Index, HDI, Poverty, Gini Index, Zakat, Democracy Index

\section{PENDAHULUAN}

Tolok ukur untuk melihat kesejahteraan suatu negara dapat dilihat dari GDP (Konferensi Bretton Woods, 1944). Variabel makro umumnya menggambarkan ukuran tumbuh kembangnya suatu negara. Akan tetapi hal ini bersifat satu dimensi saja. Salah satu titik lemah seperti yang disampaikan Bergh (2009), yaitu efek penghasilan mengakibatkan dampak pada terhadap lingkungan sekitar. Fleurbaey (2009) mengungkapkan bahwa GDP menjadi tolak ukur ekonomi, beberapa dampaknya ialah memberikan efek lingkungan. Oleh karena itu perhatian terkait pembangunan tidak hanya melihat dari sisi Beyond Gross Domestic Product (moneter). Tentunya hal ini tidak hanya melihat keadaan melalui sisi substansi saja akan tetapi ditinjau dari sisi kebahagiaan yang bersifat non materill.

Helliwell (2012) dalam World Happines Report mengungkapkan bahwa ukuran pembangunan bukan hanya GDP, Inflasi dll belum cukup menggambarkan sejahteranya suatu masyarakat akan tetapi ada ukuran lainnya yang bukan hanya ukuran materi (monetary-based indicator). Ada dua ukuran untuk merepresentasikan yang bertama bersifat (obyektif) dilihat 
dari PDRB per kapitanyadan kedua berdasarkan ukuran personal yang dpat dilihat dari indeks kebahagiaan.

\section{Gambar. 1.1 Skor Kebahagiaan Indonesia 2006-2020}

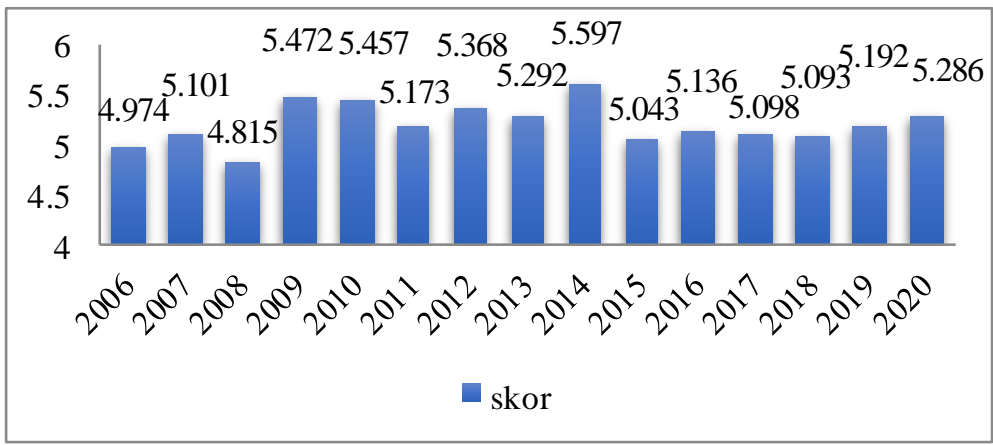

Grafik diatas berdasarkan WHR dari tahun 2006-2020 hasilnya berfluktuatif setiap tahunnya. Setiap tahunnya mengalami peningkatan serta penurunan hal ini menarik untuk diteliti untuk mengatahi factor yang mempengaruhi kebahagiaan. Penelitian yang dilakukan oleh Landiyanto (2011) dan Sohn (2014) ada dua aspek yang mempengaruhi pertama materi dan aspek non materi. Ketika aspek materi meningkat maka kebutuhan juga terpenuhi, untuk aspek non materi yaitu adanya relasi sosial yang terjalin pada lapisan masyarakat (Diener \& Seligman, 2004, Kesebir \& Diener, 2008).

Ribeiro \& Lemos Marinho (2017), hasil penelitiannya menunjukkan bahwa pendapatan tidak serta merta menentukan kebahagiaan. Ada beberapa temuan empiris dianyaranya ialah factor yang mempengaruhi kebahagiaan ialah kesehatan, pendapatan, pendidikan, dan modal sosial. Atas dasar ini penulis ingin mengetahui pengaruh dari Indeks Pembangunan manusia yang diwakili oleh Kesehatan, Pendidikan, dan Pendapatan terhadap kebahagiaan yang ada di Indonesia.

Pembangunan suatu negara erat kaitannya dengan ketimpangan yang ada disuatu negara. Ketika kemiskinan tinggi tentunya hal ini berdampak pada sejahteranya suatu negara (Wibowo, 2016). Untuk itu penulis menggabungkan terkait kebahagiaan yaitu dengan aspek dukungan social yang mana dalam penelitian ini digambarkan melalui Zakat, infaq dan shodaqoh (ZIS). Devi (2018) UNDP Membagi kedalam tiga aspek yaitu pendidikan, kesehatan, ekonomi sebagai ukuran pembangunan. Berbeda dengan Islam yaitu konsep pembangunan tidak hanya bersifat duniawi akan tetapi antara dunia dan akhirat perlu adanya keseimbangan. 
Faktor lainnya yang dikemukakan oleh GNH atau (Gross National Happiness) demokrasi ikut serta berpngaruh terhadap kebahagiaan. Ketika seseorang bebas dalam mengeluarkan aspirasinya serta membuat pilihan berdasarkan nuraninya. Dari pemaparan diatas penulis tertarik untuk meneliti Determinan Indeks Kebahagiaan di Indonesia.

\section{Jenis Penelitian}

\section{METODE PENELITIAN}

Penelitian ini menggunakan dengan pendekatan deskriptif Kuantitatif, yaitu untuk mengetahui tingkat kebahagiaan di Indonesia, berdasarkan variabel pendidikan, kesehatan, PDRB Per kapita, kemiskinan, Indeks Gini, ZIS dan Indeks Demokrasi di Indonesia

Objek pada penelitian ini meliputi 34 Provinsi Indonesia pada tahun 2014 dan 2017. Periode waktu dipilih berdasarkan ketersediaan data yang dipublikasi. Penelitian ini menggunakan data sekunder, yang diperoleh dari BPS.

\section{Metode Analisis Data}

Penelitian ini menggunakan model data panel yang diperoleh dari 34 Provinsi yang ada diIndonesia. Data diperoleh dari (BPS) dan variabel zakat diperoleh dari BAZNAZ. Menurut Damodar N. Gujarati (2007) analisis panel adalah "pengembangan alat analisis regresi sederhana terhadap aplikasi yang mencakup dua atau lebih variabel independen atau variabel prediktor untuk menduga variabel dependen atau variabel respon". Adapun model yang dirumuskan sebagai berikut:

$$
\begin{gathered}
\mathrm{IKit}=\alpha+\beta 1 \mathrm{PDRB} 1 \text { it }+\beta 2 \mathrm{AHH} 2 \mathrm{it}+\beta 3 \mathrm{RLS} 3 \mathrm{it}+\beta 4 \mathrm{KM} 4 \mathrm{it}+\beta 5 \mathrm{IG} 5 \mathrm{it}+\beta 6 \text { ZIS6it }+ \\
\beta 7 \mathrm{IDI} 7 \mathrm{it}+\varepsilon_{i}
\end{gathered}
$$

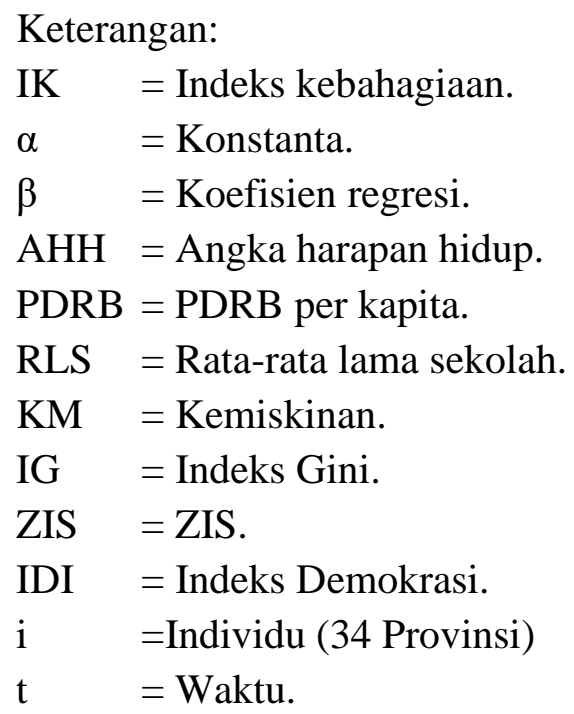




\section{Uji Spesifikasi Model}

Ada tiga uji yang digunakan untuk menentukan teknik yang paling tepat untuk mengestimasi regresi data panel. Pertama, uji statistic $\mathrm{F}$ yang digunakan untuk memilih antara metode CEM (common effect) atau (fixed effect). Kedua, uji Hausman test digunakan untuk memilih antara metode fixed effect atau random effect. Ketiga, uji LM digunakan untuk memilih antara CEM (common effect) atau GLS (random effect).

\section{Uji Chow}

Prosedur Uji chow atau (Chow test) adalah teknik untuk menguji model Common Effect dan Fixed Effect. Teknik pengujian ini untuk menentukan model manakah yang terbaik apakah Common Effect (CE) ataukah Fixed Effect (FE) yang paling tepat. Hipotesis yang dibangun yaitu $\mathrm{H}_{0}$ ditolak jika nilai dari probabilitas $\mathrm{F}$ lebih kecil dari pada alpha yaitu 0.05 dan sebaliknya.

Hipotesis:

$\mathrm{H}_{0}$ : Common Effect Model

$\mathrm{H}_{1}$ : Fixed Effect Model

\section{Uji Hausman}

Macam Uji Hausman (Hausman test) dilakukan untuk melihat model manakah yang terbaik untuk digunakan pada sebuah penelitian, model yang di uji yaitu Random Effect dan Fixed Effect. Nantinya akan di pilih model manakah yang paling terbaik dari kedua model tersebut. Model fixed effect terpilih jika nilai sig lebih kecil dari alpha 5\% atau 0,05 dan sebaliknya jika lebih besar dari alpha 5\% maka yang terpilih adalah model Random Effect.

Hipotesis:

$\mathrm{H}_{0}$ : REM

$\mathrm{H}_{1}$ : FEM

\section{HASIL DAN PEMBAHASAN}

Hasil Bagian Untuk mengestimasi model regresi dengan data panel, biasanya digunakan melalui tiga pendekatan: Pertama yaitu Common Effect Model (CEM), Kedua yaitu Fixed Effect Model (FEM) dan ketiga, yaitu Random Effect Model (REM). Untuk memilih model yang paling tepat di antara ketiga model tersebut maka dilakukan uji Chow dan uji Hausman sebagai berikut:

\section{Uji Chow}

Uji Chow dilakukan untuk melihat model mana yang paling terbaik antara Common Efect dan Fixed Effect. Hasil pengolahan dapat dilihat sebagai berikut: 
Tabel. 1.2 Hasil Uji Chow

\begin{tabular}{llll} 
Effects Test & Statistic & d.f. & Prob. \\
\hline \hline Cross-section F & 2.552356 & $(16,44)$ & 0.0072 \\
Cross-section Chi-square & 44.645417 & 16 & 0.0002 \\
Sumber: Output Eviews (data diolah) & & &
\end{tabular}

Chi-Sq.

Test Summary

Statistic Chi-Sq. d.f. Prob.

$\begin{array}{lll}16.39932 & 7 & 0.0217\end{array}$

Formulasi Hipotesi

$\mathrm{H}_{0}$ : Model CEM $>0,05$

$\mathrm{H}_{\mathrm{a}}$ : Model FEM $<0,05$

Dari hasil uji chow di atas dapat dilihat dari nilai probabilitas yaitu sebesar 0.0072 artinya lebih kecil dari alpha 0.05. Maka dalam uji ini terpilih model Fixed Effect. Akan tetapi untuk melihat model random maka akan dilanjutkan menggunakan uji hausman test.

\section{Uji Hausman}

Pengujian selanjutnya adalah uji random effect dan fixed effect atau hausman test. Apabila pada pengujian hausman test $\mathrm{H} 0$ diterima atau > 0,05 maka pengujian selesai sampai disini. Berikut adalah hasil dari pengujian Hausman test:

\section{Tabel 1.3 Hasil Uji Hausman}

Chi-Sq.

Test Summary Statistic Chi-Sq. d.f. Prob.

Cross-section randm

$$
\begin{array}{lll}
16.39932 & 7 & 0.0217
\end{array}
$$

Berdasarkan hasil uji haustman di atas diketahui bahwa nilai probabilitas sebesar 0,0217 . maka artinya nilai prob lebih dari 0.05 . Pada pengujian ini, $\mathrm{H}_{0}$ di tolak berarti model terbaik yang terpilih pada penelitian ini adalah model Fixed Effect.

Berdasarkan hasil estimasi uji chow dan uji hausman di atas, maka terpilihlah model yang terbaik yaitu Fixed Effect Method (FEM), yang dapat dilihat pada tabel berikut:

Tabel 1.4 Hasil Regresi Fixed Effect Method

\begin{tabular}{lllll} 
Variable & Coefficient & Std. Error & t-Statistic & Prob. \\
\hline \hline C & 28.28496 & 15.99783 & 1.768050 & 0.0840 \\
PDRB & -0.015038 & 0.015974 & -0.941410 & 0.3516 \\
RLS & 2.030697 & 0.483825 & 4.197172 & 0.0001
\end{tabular}




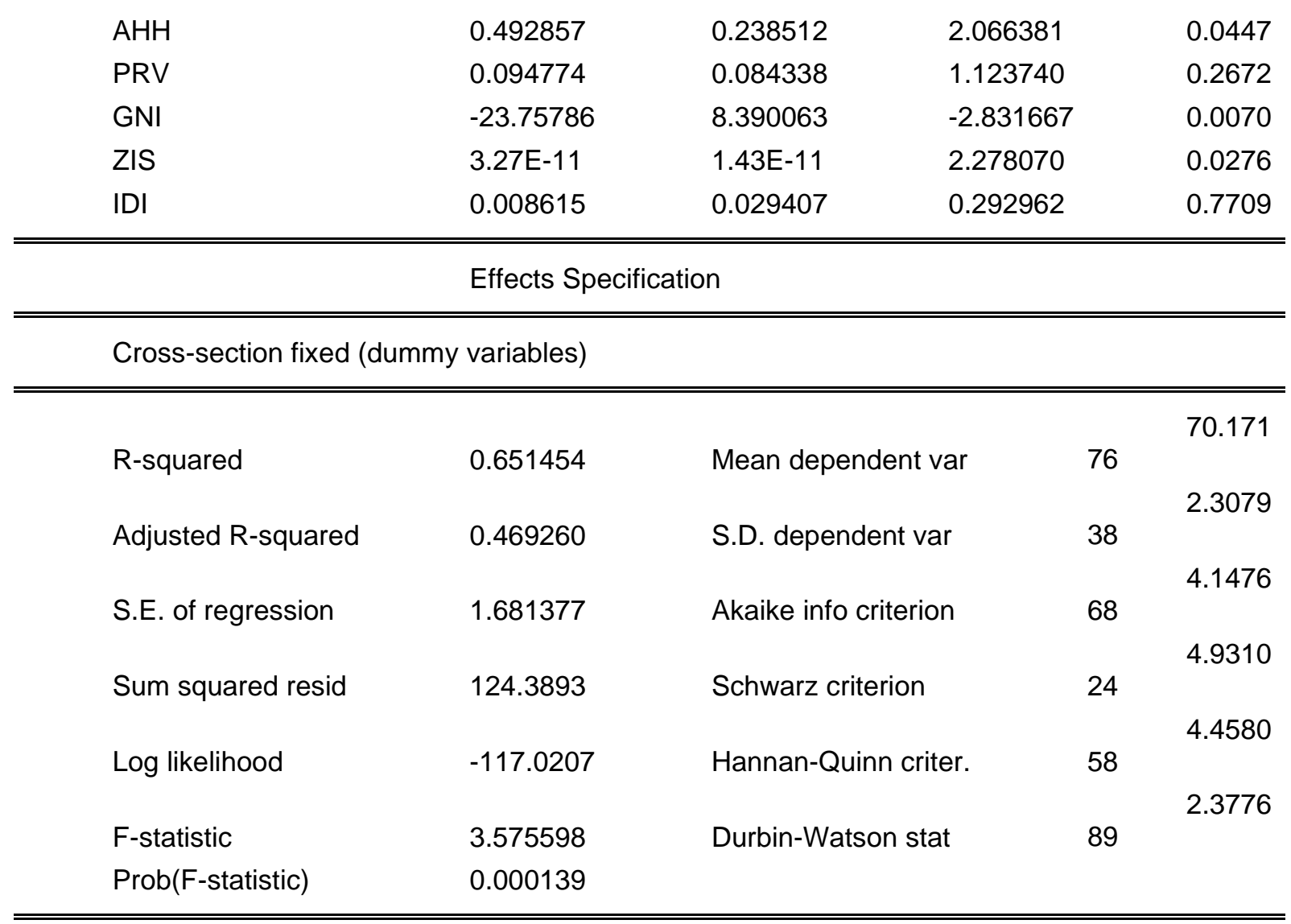

\section{Sumber: Output Eviews (data diolah)}

\section{Uji Statistik}

Dalam Penelitian ini dilakukan uji statistik yang meliputi Koefisien Determinasi $\left(\mathrm{R}^{2}\right)$, kemudian uji signifikansi bersama-sama (Uji F), dan uji signifikansi parameter individual (Uji t)

\section{Koefisien Determinasi $\mathbf{R}^{2}$}

Berdasarkan hasil regresi yang ditunjukkan pada tabel di atas, maka variabel PDRB, Rata-rata Lama Sekolah (RLS), Angka Harapan Hidup (AHH), Kemiskinan (PRV), Indeks Gini (Gni), Zakat, infak \& sedekah (ZIS) dan Demokrasi (DM) terhadap Indeks Kebahagiaan (Happ) di Indonesia Tahun 2014 dan 2017 diperoleh nilai R ${ }^{2}$ atau Adjusted R-squared sebesar 0.469260. Artinya bahwa variasi dari variabel independen mampu menjelaskan sebesar $46 \%$. sedangkan sisanya yaitu 54\% dijelaskan oleh variabel-variabel di luar penelitian ini.

\section{Uji F}

Uji F dilakukan untuk melihat ada atau tidaknya pengaruh bersama-sama (simultan) yaitu PDRB, Rata-rata Lama Sekolah (RLS), Angka Harapan Hidup (AHH), Kemiskinan (PRV), Indeks Gini (Gni), Zakat, Infak \& Sedekah (ZIS) dan Demokrasi (DM) terhadap 
Indeks Kebahagiaan (Happ) di Indonesia. Berdasarkan Hasil regresi pada dengan menggunakan model Fixed Effect maka diperoleh nilai $\mathrm{F}$ sebesar 3.575598 dengan probabilitas sebesar 0.000139, sehingga dapat kita simpulkan bahwa seluruh variabel Independen secara bersama-sama (simultan) berpengaruh secara signifikan terhadap variabel dependen.

\section{Uji t}

Uji t atau uji parsial adalah ukuran untuk menunjukkan masing-masing variabel independen secara individu (parsial) signifikan mempengaruhi variabel dependen. Berdasarkan tabel di atas diketahui bahwa t-hitung untuk variabel Rata-rata Lama Sekolah (RLS) sebesar 2.030697 dengan probabilitas 0,0001 signifikan pada $\alpha$ 5\%. maka dijelaskan bahwa variabel RLS berpengaruh positif signifikan terhadap indeks kebahagiaan di Indonesia. Variabel Angka Harapan Hidup (AHH) dengan t sebesar 0.492857 dengan probabilitas 0,0447 signifikan pada $\alpha$ 5\%. maka dijelaskan bahwa variabel AHH berpengaruh positif signifikan terhadap indeks kebahagiaan di Indonesia. Variabel Indeks Gini (GNI) dengan $\mathrm{t}$ sebesar -23.75786 dengan probabilitas 0.0070 signifikan pada ó 5\%. maka dijelaskan bahwa variabel GNI berpengaruh negatif signifikan terhadap indeks kebahagiaan di Indonesia. Variabel ZIS (ZIS) dengan t sebesar 3.27E-11 dengan probabilitas 0.0276 signifikan pada ó 5\%. maka dijelaskan bahwa variabel AHH berpengaruh positif signifikan terhadap indeks kebahagiaan di Indonesia. Sedangkan untuk variabel independen lainnya seperti PDRB, Kemiskinan, dan Indeks Demokrasi tidak berpengaruh signifikan terhadap indeks kebahagiaan (Happ) di Indonesia.

\section{Pembahasan}

\section{Pengaruh PDRB Perkapita terhadap Indeks Kebahagiaan Indonesia}

Berdasarkan hasil estimasi model Fixed Effect menunjukkan variabel Produk Domestik Regional Bruto (PDRB) tidak berpengaruh signifikan terhadap indeks kebahagiaan di Indonesia. Oleh sebab itu statistik PDRB Per kapita belum mampu mempengaruhi tingkat kebahagiaan di Indonesia. Artinya menandakan bahwa masyarakat yang memiliki pendapatan yang tinggi belum tentu disertai dengan kebahagiaan yang diperoleh.

Penelitian yang dilakukan oleh Sacks (2010) di 69 negara yang mana hasilnya menunjukkan bahwa orang-orang yang tinggal di negara kaya cenderung lebih bahagia dibandingkan dengan orang-orang yang berada di negara miskin. Sedangkan pada penelitian ini digunakan 34 sampel provinsi diseluruh Indonesia yang menunjukkan hasil yang berbeda. Variabel PDRB tidak berpengaruh secara signifikan terhadap kebahagiaan di Indonesia. Hal 
ini di dukung oleh penelitian yang dilakukan oleh Wibowo (2016) salah satu dosen UIN Sunan Kalijaga yang menemukan bahwa diantara variabel PDRB perkapita, Kemiskinan dan indeks gini hanya kemiskinan yang berpengaruh secara signifikan, sedangkan PDRB tidak mampu mempengaruhi kebahagiaan di Indonesia. penelitian lain yang mendukung yaitu Azimah Nurpita (2017) dan Hu (2012) yang sama-sama menunjukkan hasil bahwa variabel PDRB Perkapita tidak mampu mempengaruhi kebahagiaan.

Penelitian ini menunjukkan bahwa hal ini sesuai dengan pernyataan dari Easterlin \& OConnor (2020) yang di kenal dengan Esterlin Paradox yang mana menyatakan bahwa peningkatan pendapatan dalam jangka waktu yang panjang tidak memiliki dampak atau efek terhadap peningkatan kebahagiaan

\section{Pengaruh Pendidikan terhadap Indeks Kebahagiaan di Indonesia}

Berdasarkan hasil estimasi model Fixed Effect menunjukkan bahwa secara individu variabel Pendidikan yang diwakili Rata-rata Lama Sekolah (RLS) memiliki pengaruh secara signifikan terhadap indeks kebahagiaan di Indonesia. Artinya bahwa ketika masyarakat berpendidikan maka kebahagiaanya jauh lebih tinggi dari pada masyarakat dengan pendidikan rendah.

Berbagai macam pendapat para ekonom terkait dengan pendidikan dan kebahagiaan menyatakan bahwa orang-orang yang memiliki tingkat pendidikan yang lebih tinggi, cenderung memiliki kesempatan kerja yang lebih baik, yang kemudian diikuti dengan pendapatan atau gaji yang tinggi dan pada akhirnya memiliki hidup yang sejahtera. Namun pernyataan ini berbanding terbalik dengan Clark \& Oswald (1994). pendidikan dan kebahagiaan memiliki hubungan yang negatif karena menurutnya pendidikan membuat orang lebih ambisius yang akan sangat mungkin menurunkan tingkat kebahagiaan karena harapan yang lebih tinggi akan sangat sulit dipenuhi.

Penelitian yang dilakukan oleh Boris Nikolaev \& Pavel Rusakof (2018) Secara keseluruhan, hasilnya menunjukkan bahwa orang yang berpendidikan tinggi, rata-rata lebih bahagia daripada rekan mereka yang kurang berpendidikan. Wan chi Hen (2012) dalam penelitiannya How Education Enhances Happiness: di Asia Timur yakni Jepang, Korea Selatan, Taiwan dan Cina menemukan bahwa individu yang menerima lebih banyak pendidikan memiliki jejaring sosial yang lebih luas. kondisi kehidupan ini berhubungan positif dengan kebahagiaan. Dengan meningkatkan kemampuan dan kecenderungan seseorang untuk terhubung dengan dunia sosial yang lebih luas, pendidikan dapat meningkatkan kesejahteraan subjektif seseorang. 
Secara Nasional juga dilakukan penelitian terkait pendidikan dan kebahagiaan yang mana dilakukan oleh Vingky Ocviandri (2020) menunjukkan bahwa dari hasil penelitian tingkat kebahagiaan di Indonesia dipengaruhi secara positif oleh pendidikan. Budidharma (2016) dan Bella Febriatikaningrum (2020) tingkat kesehatan dan pendidikan yang tercermin dari IPM memiliki pengaruh positif terhadap tingkat kebahagiaan. Semakin tinggi tingkat pendidikan individu maka semakin tinggi kebahagiaannya

\section{Pengaruh Kesehatan terhadap Indeks Kebahagiaan di Indonesia}

Berdasarkan hasil estimasi model Fixed Effect menunjukkan bahwa secara Individu variabel Kesehatan yang diwakili Oleh Angka Harapan Hidup (AHH) memiliki pengaruh secara signifikan terhadap indeks kebahagiaan di Indonesia. Ketika masyarakat sehat jasmani maupun rohani tentunya akan berpengaruh terhadap kebahagiaan begitupun sebaliknya.

Pada penelitian ini mendapatkan output variabel kesehatan berpengaruh secara positif signifikan terhadap kebahagiaan di Indonesia. Hal ini didukung oleh beberapa penelitian yaitu: Penelitian yang dilakukan oleh Veenhoven (1988) penelitian ini menunjukkan hubungan yang positif. Ia juga menemukan bahwa orang yang bahagia hidup lebih lama, mungkin dikarenakan kebahagiaan melindungi kesehatan fisik. juga demikian penelitian dari Cunado (2012) menemukan efek langsung dan tidak langsung. secara tidak langsung kesehatan yang lebih baik mempengaruhi tingkat kebahagiaan Budidharma (2016) semakin sehat kondisi Individu, tingkat kebahagiaan juga akan meningkat.

\section{Pengaruh kemiskinan terhadap indeks kebahagian di Indonesia}

Berdasarkan hasil estimasi model Fixed Effect menunjukkan bahwa variabel kemiskinan tidak berpengaruh secara signifikan terhadap indeks kebahagiaan di Indonesia. Artinya menandakan bahwa masyarakat miskin bukanlah satu faktor penyebab kebahagiaan individu menurun rendah. Artinya kemiskinan bukanlah sebuah ukuran untuk menentukan bahagia atau tidaknya suatu masyarakat.

Memang harus diakui bahwa kemiskinan merupakan masalah utama dalam semua Negara. Selama periode 2016 - 2017 Badan Pusat Statistik (BPS) mengkonfirmasi bahwa indeks kemiskinan di Indonesia semakin dalam dan semakin parah. Kepala BPS Suharyanto mengatakan, indeks kedalaman kemiskinan pada Maret 2017 mencapai 1,83, naik dari September yang hanya 1,74. Hal ini menandakan bahwa ketika indeks kedalaman (kemiskinan) naik maka tingkat kemiskinan semakin tinggi.

Hasil Penelitian ini didukung oleh Penelitian yang dilakukan oleh Camfield, Chondhury, \& Devine (2007) Well-being, Happiness and Why Relationship Matter: Evidence 
from Bangladesh mengungkap adanya faktor-faktor sosial budaya yang memengaruhi kebahagiaan seseorang meskipun orang tersebut mengalami kemiskinan, sehingga penduduk Bangladesh tetap merasa bahagia.

Jaafar (2012) meneliti faktor penentu dari kebahagiaan pada 202 penduduk Malaysia dan Indonesia. Hasil yang didapatkan cukup menarik perhatian yaitu yang menjadi faktor utama dalam menentukan kebahagiaan adalah keluarga. 28\% faktor keluarga dipilih oleh responden dalam menentukan kebahagiaan mereka. Kedua hubungan sosial dengan perolehan persentase $14 \%$ dalam penentu kebahagiaan. Dan ketiga kesehatan menjadi penentu kebahagiaan dengan perolehan $7,8 \%$.

\section{Pengaruh Indeks gini terhadap indeks kebahagiaan di Indonesia}

Berdasarkan hasil estimasi model Fixed Effect menunjukkan bahwa variabel indeks gini berpengaruh secara signifikan terhadap indeks kebahagiaan di Indonesia. Hal ini mengindikasikan bahwa secara statistic adanya ketimpangan yang terjadi dimasyarakat mempengaruhi tingkat kebahagiaan di Indonesia. artinya orang-orang yang lebih kaya merasakan kebahagiaan yang lebih dibandingkan dengan orang-orang berada dikategori miskin. Kesenjangan sosial ini sangat mempengaruhi tingkat kebahagiaan seseorang.

Berdasarkan Easterlin paradox (1995) yaitu menyatakan bahwa kekayaan yang berlebih tidak mengarah pada lebih banyak kebahagiaan. hal ini diartikan sebagai ketidakpuasan individu dengan kehidupannya karena selalu membandingkan diri mereka sendiri dengan orang lain. Festinger (1954) terdapat 2 jenis teori perbandingan sosial. Teori pertama Perbandingan ke atas: yaitu membandingkan diri sendiri dengan dengan orang-orang yang berstatus sosial lebih tinggi dan berkehidupan lebih baik. Sedangkan perbandingan ke bawah membandingkan dirinya dengan orang-orang yang berstatus sosial lebih buruk.

Secara realita teori perbandingan ke atas lebih signifikan dari pada perbandingan ke bawah Ferrer-i-Carbonell (2005), hal ini akan mengakibatkan ketika pendapatan absolut bertambah maka mereka cenderung akan membandingkan dengan yang lebih kaya, yang mana ini akan menurunkan kesejahteraan subyektifnya. Akibatnya akan terjadi kesenjangan pendapatan antara si kaya dan si miskin. Studi empiris telah menunjukkan hubungan yang signifikan antara kesenjangan pendapatan dan kebahagiaan (Brockmann 2009, Oishi 2011)

Terdapat beberapa penelitian empiris yang beragam terkait dengan kesenjangan pendapatan dan kebahagiaan. Hal ini dibuktikan dengan penelitian yang dilakukan oleh Zonghuo Yu \& Fei Wang (2017) Hasil penelitian menunjukan bahwa indeks gini berpengaruh negatif signifikan terhadap kebahagiaan. Kemudian penelitian yang dilakukan 
oleh Alesina (2004) menunjukkan ketimpangan pendapatan berhubungan negatif dengan kebahagiaan.

Penelitian yang dilakukan oleh Shigehiro Oishi (2011) menunjukkan bahwa hubungan negatif antara ketimpangan pendapatan dan kebahagiaan responden berpenghasilan rendah dijelaskan bukan oleh pendapatan rumah tangga yang lebih rendah, tetapi oleh ketidakadilan yang dirasakan dan kurangnya kepercayaan. Penelitian yang dilakukan oleh Carol Graham (2006) menemukan bahwa ketidaksetaraan memiliki efek negatif pada kebahagiaan di Amerika Latin, di mana tampaknya menjadi sinyal ketidakadilan yang terus-menerus.

\section{Pengaruh ZIS terhadap Indeks kebahagiaan di Indonesia}

Berdasarkan hasil estimasi model menunjukkan bahwa variabel ZIS berpengaruh signifikan terhadap indeks kebahagiaan di Indonesia. Hal ini mengindikasikan bahwa adanya bentuk dukungan sosial berupa ZIS mempengaruhi tingkat kebahagiaan di Indonesia. artinya orang-orang yang mendapatkan bantuan atau dukungan sosial cenderung merasakan peningkatan kebahagiaan.

Secara teori dijelsaskan Smet (1994) bahwa dengan adanya dukungan sosial seseorang dapat memperoleh manfaat atas apa yang ia terima. Dukungan sosial yang diterima membuat seseorang merasa lebih diperhatikan. The World Happiness Report (2018), dalam laporannya menyatakan bahwa (subjective-well being) yang diukur menggunakan skala 0-10 mencakup enam variabel salah satunya adalah dukungan sosial. Artinya semakin tinggi dukungan sosial yang didapat, maka semakin tinggi kebahagiaan yang dirasakan oleh mustahik. Hal ini didukung oleh penelitian yang dilakukan oleh Marni \& Yuniawati (2015) Setiap Individu yang menerima dukungan social akan memperoleh manfaat atas apa yang diterimanya. Penelitian lain dilakukan oleh Nur Azimah (2017) dalam penelitiannya terkait dengan hubungan Dukungan sosial (zakat) dan kebahagiaan memberikan hasil adanya hubungan positif antara dukungan sosial dengan kebahagiaan mustahik

\section{Pengaruh Indeks Demokrasi Terhadap Indeks Kebahagiaan di Indonesia}

Berdasarkan hasil estimasi model Fixed Effect menunjukkan bahwa variabel indeks Demokrasi tidak berpengaruh secara signifikan terhadap indeks kebahagiaan di Indonesia. Hal ini mengindikasikan bahwa secara statistik nilai demokrasi yang diwakili oleh kebebasan sipil belum mampu mempengaruhi tingkat kebahagiaan di Indonesia. Artinya kebebasan untuk menyatakan pendapat, kebebasan untuk memilih pemimpin belum mengindikasikan peningkatan kebahagiaan di Indonesia. 
Wijaya (2016) Secara teori Jean Jaques Rousseau, demokrasi berperan penting dalam mencapai kesejahteraan atau kebahagiaan pada sebuah Negara. Teori dari Rousseau ini seakan menyimpulkan bahwa demokrasi pada sebuah Negara adalah sebuah upaya dalam mencapai perkembangan ketatanegaraan yang sempurna. Hans Kelsen juga menguraikan pendapatnya terkait hal ini. Menurutnya demokrasi menjadi lebih tertata dan sistematis. Hal Ini membuktikan, bahwa demokrasi adalah sebuah proses untuk mencapai kesempurnaan.

Hasil penelitian ini didukung oleh penelitian yang dilakukan oleh Fischer (2007) yang meneliti adanya hubungan positif yang signifikan antara kebahagiaan dan demokrasi. Kemudian penelitian yang dilakukan oleh Frey dan Stutzer (2000) Hasil dari penelitian ini mengungkapkan bahwa democracy secara langsung akan meningkatkan kepuasan pada masyarakat Swiss yang mana hubungannya positif signifikan. Weiner (2008) juga menemukan korelasi positif antar demokrasi dan kebahagiaan. Senada dengan riset diatas Welzel \& Inglehart (2006) mengungkapkan demokrasi memang berpengaruh pada kebahagiaan, tetapi walaupun begitu hubungannya bisa saja negatif ketika terjadi demokratisasi.

\section{KESIMPULAN DAN SARAN}

Penelitian ini bertujuan untuk menguji beberapa variabel diantaranya ialah Indeks Pembangunan Manusia yang diwakilkan oleh PDRB, Pendidikan dan Kesehatan, kemudian Kemiskinan, Indeks gini, ZIS, dan Indeks Demokrasi terhadap tingkat kebahagiaan di Indonesia. Hasil menunjukkan variabel PDRB Per Kapita tidak berpengaruh secara signifikan terhadap kebahagiaan di Indonesia. Variabel kedua yaitu Pendidikan berpengaruh secara signifikan terhadap kebahagiaan di Indonesia. Kesehatan berpengaruh signifikan terhadap kebahagiaan di Indonesia. Kemiskinan tidak berpengaruh secara signifikan terhadap kebahagiaan di Indonesia. Indeks gini berpengaruh negatif signifikan terhadap kebahagiaan di Indonesia. ZIS berpengaruh positif signifikan terhadap kebahagiaan di Indonesia. Sedangkan variabel Indeks demokrasi yang tercermin pada aspek kebebasan sipil tidak berpengaruh secara signifikan terhadap kebahagiaan di Indonesia.

Adapun saran untuk penelitian selanjutnya yaitu: 1) Masih terdapat banyak sekali indikator diluar sana yang dapat mempengaruhi kebahagiaan seseorang. Oleh karenanya diharapkan untuk penelitian selanjutnya cermat dalam pemilihan variabel untuk memperoleh hasil yang bervariasi, sehingga hal ini akan memperkaya pengetahuan kita tentang faktor mendasar kebahagiaan di Indonesia. 2) Pada penelitian selanjutnya diharapkan untuk 
mengembangkan metode pengujiannya sehingga hasil yang didapat cukup efektif untuk mengetahui pengaruhnya terhadap kebahagiaan di Indonesia.

\section{DAFTAR PUSTAKA}

A. Alesina. R (2004). Inequality and happiness: Are Americans and Europeans different?. Journal of Public Economics. Vol 88

Ani Marni, Rudy Yuniawati. 2015. Hubungan Antara Dukungan Sosial Dengan Penerimaan Diri Pada Lansia Di Panti Wredha Budhi Dharma Yogyakarta. Jurnal Fakultas Psikologi. Vol.3 No.1

Azimah, S. N. (2017). Hubungan Antara Dukungan Sosial Lembaga Zakat Dengan Kebahagiaan Pada Mustahik.

BPS (2017) https://www.bps.go.id/pressrelease/2013/01/02/165/september-2012--jumlahpenduduk-miskin-indonesia-mencapai-29-13-juta-orang.html

Bergh, J. C. J. M. va. den. (2009). The GDP paradox. Journal of Economic Psychology, 30 (2), 117-135. https://doi.org/10.1016/j.joep.2008.12.001

Boris Nikolaev (2018) Does higher education increase hedonic and eudaimonic happiness?. Journal of happiness Studies. Springer Netherlands. Hal 483-504

Brockmann, Hilke Delhey, Jan Welzel, ChristianYuan, Hao. (2009) The China Puzzle: Falling Happiness in a Rising Economy. The Journal of Human Resources. Vol $8: 4$ Page 436.

Budidharma. I (2016) Pengaruh Pengeluaran Konsumsi, Status Kesehatan Dan Modal Sosial Terhadap Tingkat Kebahagiaan Individu.

http://bappeda.jogjaprov.go.id/artikel/detail/57-pengaruh-pengeluaran-konsumsistatus-kesehatan-dan-modal-sosial-terhadap-tingkat-kebahagiaan-indiv

Camfield, Chondhury. D (2007) Well-being, Happiness and Why Relationships Matter: Evidence from Bangladesh. Journal of Happiness Studies 2007 10:1. Page 71-91

Clark, A., Oswald, A. J., Clark, A., \& Oswald, A. (1994). Unhappiness and Unemployment. Economic Journal, 104(424), 648-659. https://econpapers.repec.org/RePEc:ecj:econjl:v:104:y:1994:i:424:p:648-59

Carol Graham. Felton, Andrew (2006) Inequality and happiness: Insights from Latin America. The Journal of Economic Inequality 2005 4:1

Cuñado, J., \& de Gracia, F. P. (2012). Does Education Affect Happiness? Evidence for Spain. Social Indicators Research, 108(1), 185-196. https://doi.org/10.1007/s11205-011-9874$\mathrm{x}$

Damodar N. Gujarati. (2007). Dasar-Dasar Ekonometrika (Edisi Ketiga). Erlangga.

Devi, S. I. (2018). Pengaruh Pengangguran, Pertumbuhan Ekonomi, Pengeluaranpemerintah Dan Kemiskinan Terhadap Indeks Pembangunan manusia (Ipm) Provinsi Banten.

Diener, E., \& Seligman, M. E. P. (2004). Beyond Money: Toward an Economy of Well-Being. Psychological Science in the Public Interest: A Journal of the American Psychological Society, 5(1), 1-31. https://doi.org/10.1111/j.09637214.2004.00501001.x

Easterlin, R. A. (1955). Does Economic Growth Improve the Human Lot? Some Empirical Evidence. In Nations and Households in Economic Growth (pp. 89-125). Elsevier. https://doi.org/10.1016/b978-0-12-205050-3.50008-7

Easterlin, R., \& OConnor, K. (2020). The Easterlin Paradox. IZA Discussion Paper, 13923. 
Festinger, L. (1954). A theory of social comparison processes. Human Relations, 7, 117-140. https://doi.org/10.1177/001872675400700202

Ferrer-i-Carbonell. (2005) Income and well-being: an empirical analysis of the comparison income effect. Journal of Public Economics, 2005, vol. 89, issue 5-6, 997-1019

Fischer, J. A. V., Kirchgässner, G., \& Sousa-Poza, A. (2007). Is it culture or democracy? The impact of democracy and culture on happiness. Social Indicators Research, 82(3), 505-526. https://doi.org/10.1007/s11205-006-9048-4DU

Fleurbaey, M. (2009). Beyond GDP: The quest for a measure of social welfare. Journal of Economic Literature, 47(4), 1029-1075. https://doi.org/10.1257/jel.47.4.1029

Frey, B. S. (2008) Happiness. The MIT Press. https://doi.org/10.7551/mitpress/9780262062770.001.0001

Helliwell, J., Layard, R., \& Sachs, J. (n.d.). World Happiness report.

$\mathrm{Hu}, \mathrm{Z}$. (2012). Chinese Happiness Index and Its Influencing Factors Analysis Zimu Hu. $1-48$.

Human Development Report 1990 | Human Development Reports. (n.d.). Retrieved April 20, 2021, from http://hdr.undp.org/en/reports/global/hdr1990

Human Development Report 2004 | Human Development Reports. (n.d.). Retrieved April 20, 2021, from http://hdr.undp.org/en/content/human-development-report-2004

Irfan Syauqi Beik, L. D. A. (2016). Measuring zakat impact on poverty and welfare using

Jaafara, JL, Idris MA, Ismuni, J, Fei, Y, Jaafar, S, Ahmad, Z, Arrif, MR, Takwin, B, Sugandi, YS. (2012). The Sources of Happiness to the Malaysians and Indonesians: Data from a Smaller Nation. Procedia - Social and Behavioral Sciences 65, 549 - 556.

Landiyanto, E. A., Ling, J., Puspitasari, M., \& Irianti, S. E. (n.d.). M P RA Munich Personal RePEc Archive Wealth and Happiness: Empirical Evidence from Indonesia. Retrieved April 19, 2021, from http://mpra.ub.uni-muenchen.de/50012/

Todaro, Michael. P. (1997). Pembangunan Ekonomi di Dunia Ketiga. Erlangga.

Siti Nur Azimah (2017) Hubungan Antara Dukungan Sosial Lembaga Zakat Dengan Kebahagiaan Pada Mustahik. Skripsi thesis, Universitas Islam Negeri Sultan Syarif Kasim Riau.

Ribeiro, L. L., \& Lemos Marinho, E. L. (2017). Gross National Happiness in Brazil: An analysis of its determinants. EconomiA, 18(2), 156-167. https://doi.org/10.1016/j.econ.2016.07.002

Sacks, D., Stevenson, B., \& Wolfers, J. (2010). Subjective Well-Being, Income, Economic Development and Growth. National Bureau of Economic Research. https://doi.org/10.3386/w16441

Smet, B. (1994). Psikologi kesehatan. Ahli bahasa: Bagus Wismanto. PT. Grasindo Persada.

Shigehiro Oishi, (2011) Income inequality and happiness. Journal Psychological Science. Vol 22:9 Page 1095-1100

Veenhoven, R. (1988). The utility of happiness. Social Indicators Research, 20(4), 333-354. https://doi.org/10.1007/BF00302332

Vingky Ocviandri (2020) Analisis Faktor-Faktor Ekonomi dan Sosial terhadap Kebahagiaan Individu dalam Rumah Tanga Di Indonesia. https://library.universitaspertamina.ac.id//xmlui/handle/123456789/882

Wan Chi Chen (2012) How Education Enhances Happiness: Comparison of Mediating Factors in Four East Asian Countries. Social Indicators Research.Vol 106-1 Page 117-131

Welzel, C., \& Inglehart, R. (2006). Emancipative values and democracy: Response to Hadenius and Teorell. Studies in Comparative International Development, 41(3), 74-94. https://doi.org/10.1007/BF02686237 
Wibowo, M. G. (2016). Asy-Syir'ah Kebijakan Pembangunan Nasional: dari Pertumbuhan (Growth) Menuju Kebahagiaan (Happiness). In Jurnal Ilmu Syari'ah dan Hukum (Vol. 50, Issue 1). https://doi.org/10.14421/ASY-SYIR'AH.2016.501-10

Wijaya, D. N. (2016). Jean-Jaques Rousseau dalam Demokrasi. Politik Indonesia: Indonesian Political Science Review, 1(1), 14. https://doi.org/10.15294/jpi.v1i1.9075

World Happiness Report 2018 | The World Happiness Report. (n.d.). Retrieved April 19, 2021, from https://worldhappiness.report/ed/2018/

Zonghuo Yu. Wang, Fei (2017) Income inequality and happiness: An inverted U-shaped curve. Journal Frontiers in Psychology. Vol. 8 